\title{
ARSENIC CONTENT AND PHENOLIC COMPOUNDS IN PARSLEY (PETROSELINUM CRISPUM (MILL.) FUSS) AND CELERY (APIUM GRAVEOLENS L.) CULTIVATED IN VOJVODINA REGION, SERBIA
}

\author{
Slobodanka P. Pajević ${ }^{1}$, Neda M. Mimica-Dukić ${ }^{2}$, Ivana M. Nemeš ${ }^{2}$, Milan D. Župunski ${ }^{1}$, Nataša D. Simin ${ }^{2}$, \\ Malcolm A. Watson ${ }^{2}$, Danijela D. Arsenov ${ }^{* 1}$ \\ ${ }^{1}$ University of Novi Sad Faculty of Sciences, Department of Biology and Ecology, Trg Dositeja Obradovića 2, \\ 21000 Novi Sad, Serbia \\ ${ }^{2}$ University of Novi Sad Faculty of Sciences, Department of Chemistry, Biochemistry and Environmental \\ Protection, Trg Dositeja Obradovića 3, 21000, Novi Sad, Serbia
}

\begin{abstract}
Randomly collected samples of parsley and celery from different localities were analysed to determine their quality based on arsenic concentrations, phenolic constituents and the antioxidant capacity of their edible parts. Arsenic concentrations were found in the range: parsley root $(0.16 \mu \mathrm{g} / \mathrm{g}$ d.m. $)<$ celery root $(0.19 \mu \mathrm{g} / \mathrm{g} \mathrm{d.m.})<$ parsley leaf $(0.35 \mu \mathrm{g} / \mathrm{g} \mathrm{d}$ d.m. $)<$ celery leaf $(0.45 \mu \mathrm{g} / \mathrm{g}$ d.m. $)$. Total phenolic contents in roots were similar in both species and varied significantly depending on the cultivation site: $5.03-9.18 \mathrm{mg}$ eqGA/g DE in parsley and 5.04-8.50 mg eqGA/g DE in celery. Lower total flavonoids content was recorded in celery. Among the phenolic acids, ferulic, chlorogenic and several cinnamic acids dominated. Apigenin and its glucosides dominated among flavonoids. Based on the principal component analysis (PCA) it can be concluded that the As content varied depending on the geographical origin of the samples. Also, phenolic compounds showed a significant contribution on PCA clustering, indicating that the cultivation site has a clear significant impact on the metabolites profile, while As content in plants did not significantly affect phenolic compound profile.
\end{abstract}

Key words: arsenic, vegetables, antioxidative response, phenolic compounds, PCA analysis

\section{INTRODUCTION}

Arsenic (As) is one of the most toxic mobile elements in the environment and is the main constituent of more than 245 minerals (Mollah, Lu \& Cocke, 1998). The average As content in the earth's crust is about $5 \mathrm{mg} / \mathrm{kg}$, and can be a lot more in volcanic and sedimentary rocks. Significant amounts of this toxic metalloid can also be introduced into the soil by anthropogenic activities. The environmental loadings of As, other metalloids and heavy metals is thus the result of numerous biogeochemical pro-

Corresponding author:

E-mail address: danijela.arsenov@dbe.uns.ac.rs cesses during natural pedogenesis, as well as deposition of particles generated by mining and smelting activities, combustion of gasoline in traffic, medical and hazardous waste incineration and municipal waste combustion (Bhattacharya, Samal, Majumdar \& Santra, 2010). A serious source of soil contamination by arsenic is application of pesticides containing As-salts, such as $\mathrm{Ca}_{3}\left(\mathrm{AsO}_{4}\right)_{2}$ and $\mathrm{Pb}_{3}\left(\mathrm{AsO}_{4}\right)_{2}$, with toxic effects on biological systems based on Astoxicity (Bencko \& Foong, 2017). Also, natural 
phosphates contain many metallic elements. After phosphate processing and production of phosphorus fertilizers, heavy metals like $\mathrm{Cd}, \mathrm{Pb}$, and As are often found in P fertilizers. Additionally, the use of animal manure may lead to increased intake of As in the soil, if non-toxic organic arsenic compounds are added to the animal food as supplements (McBride \& Spiers, 2001).

Due to the extremely high capacity of As for adsorption and fixation on soil particles, there is a noticeable increase in its accumulation into the soil surface layers with higher contents of clayand organic-particles. Additionally, As can be strongly adsorbed to soils and are therefore transported only over short distances in groundwater and surface water (Wuana \& Okieimen, 2011). The predominant oxidation states of As under oxic and reducing environmental (soil) conditions are: arsenate $[\mathrm{As}(\mathrm{V})]$ and arsenite [As(III)]. Phosphorus and arsenic have competitive reactions in soils and there is plenty of evidence indicating that phosphate plays a significant role in regulating the ratio between differrent forms of bioavailable arsenic ions (Finnegan \& Chen, 2012). Plants can uptake the very toxic arsenite [As(III): $\mathrm{As}_{2} \mathrm{O}_{3}, \mathrm{AsO}^{2-}$, $\left.\mathrm{AsO}_{3}{ }^{3-}\right]$ form that may exist under reducing soil conditions or be rapidly produced within the root tissue by enzymatic reduction of $\mathrm{As}(\mathrm{V})$. After absorption, plant physiological defence mechanisms against the toxic impact of As most often imply its chelatization with peptides phytochelatins, sequestration and accumulation in cell walls and/or vacuoles. There are indications that complexation of As(III) with phytochelatins in plant cells decreases its mobility for root-to-shoot translocation in specific plant species (Liu et al., 2010).

According to many scientific reports and the Strategy of water supply and water protection in Autonomous Province of Vojvodina, many of the groundwater reservoirs used for water supply in this part of Serbia contain unacceptably high concentrations of arsenic exceeding the limit of $10 \mu \mathrm{g} \mathrm{As} / \mathrm{L}$ (Strategy of water supply and water protection in AP Vojvodina, 2009). Longterm irrigation by contaminated groundwater, wastewater, as well as the regular usage of artificial fertilizers and pesticides in agricultural practices can lead to a real danger of environ9 mental arsenic accumulation and its entry into food chains. Arsenic exposure through drinking water and contaminated food is therefore a glo- bal public health problem which carries enhanced risk since arsenic does not have colour, odour or taste, so it is not recognizable in daily consumption (Kapaj, Peterson, Liber \& Bhattacharya, 2006).

One of the adverse effects of excess amounts of arsenic in plants is the generation of reactive oxygen species (ROS) leading to oxidative stress (Kostecka-Gugała \& Latowski, 2018). As a consequence, plants activate diverse mechanisms of antioxidant defence, including several enzymes and non-enzymatic molecules. Among various classes of plant secondary metabolites which participate in plant antioxidant protection, phenolic compounds including phenylpropanoids, coumarins, flavonoids, tannins etc. are defined as powerful ROS and peroxides scavengers, inhibitors of lipid peroxidation, and metal ions chelators (Mišan, 2011; Beara et al., 2012). Enhanced amounts of phenolic compounds in plants can be induced by excessive heavy metals in plant tissues (Arsenov et al., 2021a). However, it is still not proven if the increase of phenolics is the result of their de novo synthesis or conjugate hydrolysis induced by heavy metal stress (Michalak, 2006). Beside their protective effect in plants, phenolics are considered as important compounds having a beneficial effect on human health. They are the most abundant antioxidants in human diets and are highly distributed in cereals, fruits, vegetables and some beverages (Cvejić Hogervorst et al., 2018). Widely distributed plant phenolics, especially dietary flavonoids, have antioxidant, antitumor, and anti-inflammatory properties and therefore can be considered as alternative sources for pharmaceutical and medicinal applications (Jain, Yadav, Bozhkov, Padalko \& Flora, 2011).

This research was organized to evaluate the accuracy of the hypothesis that different geographical origin and cultivation practice influence arsenic accumulation in vegetables. Withal, depending on species and accumulated arsenic, plants can exhibit specific antioxidative metabolic response, all resulting in specific nutritional value and safety for use in human diet. Therefore, this work aimed to examine the concentrations of arsenic in edible parts of parsley (Petroselinum crispum (Mill.) Fuss) and celery (Apium graveolens L.) samples randomly collected from sites where vegetables are cultivated by conventional plant production practice and by watering with available water from natural 
streams and wells. Also, the research was organized to define quality and health safety of parsley and celery by evaluating the plants physiological response to oxidative damage and antioxidant capacity, including synthesis of phenolic constituents.

\section{MATERIALS AND METHODS}

\section{Vegetable sampling}

The nutritional value and health safety of parsley (Petroselinum crispum (Mill.) Fuss) and celery (Apium graveolens L. var. rapaceum) were investigated based on arsenic concentration and phenolic antioxidant compounds accumulation in their edible parts. Plant samples, including roots and leaves of both species, were collected randomly at green markets, from individual producers, who cultivated vegetables in Vojvodina Province, by applying conventional methods, which implies the use of fertilizers and control of pests. Samples were collected during September and October at full maturity of plants, to ensure that plants are not stored for a long period. Aiming to ensure that plants are locally produced, a short survey was conducted for each seller about the place and manner of growing vegetables. Vojvodina is located in the southern Pannonian plain, in the northern part of Serbia. The agricultural land encompasses over $75 \%$ of the total area of Vojvodina, where the drainage channel network is around $20000 \mathrm{~km}$ (Savić, Ondrasek \& Josimov-Dundjerski, 2015).

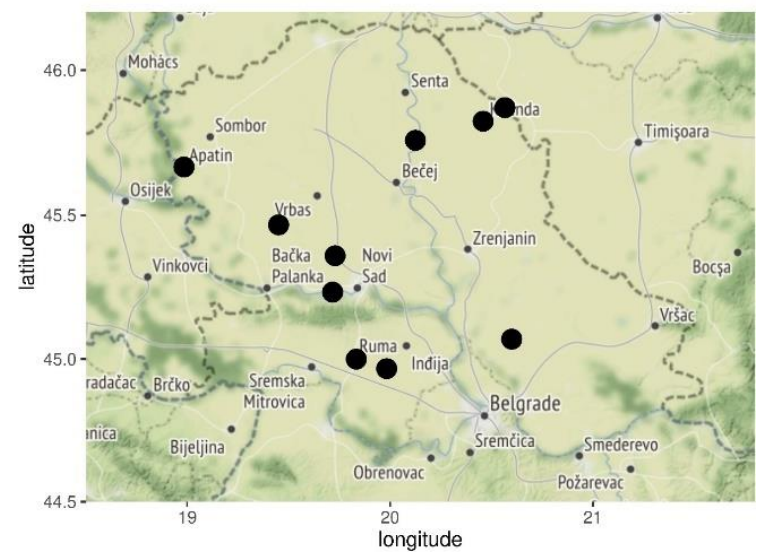

Figure 1. Geographical map of Vojvodina region with indications of the localities where vegetables were cultivated

The majority of agricultural land (98\%) is represented by arable land areas, favourable for the cultivation of most vegetable species, presenting around $10 \%$ of total arable areas. Plant samples of parsley and celery were taken randomly from
10 different localities, where the latitudes range from $44^{\circ} 87^{\prime}$ to $46^{\circ} 05^{\prime} \mathrm{N}$, and longitudes from $19^{\circ} 01^{\prime}$ to $20^{\circ} 39^{\prime}$ E (Fig. 1) markets. Parsley roots (Petroselinum crispum cultivar Berlin) was taken from 7 different localities, parsley leaves (Petroselinum crispum ssp. crispum) from 8, celery roots (Apium graveolens var. rapaceum) from 7 and celery leaves (Apium graveolens var. secalinum) from 5 localities, variation among some samples was made due to the available vegetables offers on green

\section{Arsenic analysis}

Fresh vegetable samples were washed in tap water, followed by washing in distilled water, to remove any surface contamination. The edible parts (roots and/or leaves) were separated, dried at $70-80{ }^{\circ} \mathrm{C}$ until constant mass, and subsequently ground. Mineralization of plant material was carried by digestion in nitric acid $(65 \%$ $\mathrm{HNO}_{3}$ ), with the addition of $33 \% \mathrm{H}_{2} \mathrm{O}_{2}$ until complete mineralization. Total As concentration in sample solutions was measured by Inductively Coupled Plasma Mass Spectrometry (ICP/MS, Agilent Technologies 7700) according to U.S. EPA (2014). The limit of quantification (LOQ) was $0.02 \mu \mathrm{g} / \mathrm{L}$ and was based on three replicates, while the percentage of relative standard deviation (RSD) was below $10 \%$. The total arsenic content is expressed as $\mu \mathrm{g}$ As per $\mathrm{g}$ of dry plant mass ( $\mu \mathrm{g} / \mathrm{g}$ d.m.).

\section{Extract preparation}

Root samples of $30 \mathrm{~g}$ dried plants material was macerated 3 times with $40 \mathrm{~mL}$ of $80 \%$ methanol, with $6 \mathrm{~h}$ stirring, using fresh solvent each time, and the macerate was filtrated through filter paper. The obtained extracts were evaporated on a vacuum evaporator at a temperature below $45^{\circ} \mathrm{C}$ until dry. The dry residue was then dissolved in DMSO so that the final concentration was $300 \mathrm{mg} / \mathrm{mL}$.

\section{Total phenolic and total flavonoid content}

The total phenolic content of the extract was measured by a Folin-Ciocalteu assay and expressed as milligrams of gallic acid (GA) equivalents per gram of dry extract (mg eq $\mathrm{GA} / \mathrm{g}$ DE) (Singleton, 1999). The total flavonoid content was determined by the aluminium chloride colorimetric method (Chang, Yang, Wen \& Chern, 2002) and expressed as milligrams of quercetin equivalents per gram of dry extract (mg eq quercetin/g DE). 


\section{Quantitative LC-MS/MS analysis of the selected phenolics}

The content of the 44 selected phenolic compounds (14 phenolic acids, 25 flavonoids, 3 coumarins and 2 lignans) was investigated by LC-MS/MS according to Beara et al. (2012). Standards of the compounds were purchased from Sigma-Aldrich Chem (Steinheim, Germany), Fluka Chemie GmbH (Buchs, Switzerland) or ChromaD.e. (Santa Ana, USA). An Agilent 1200 series liquid chromatograph, coupled with Agilent series 6410B electrospray ionization triple-quadrupole mass spectrometer and controlled by MassHunter ver. B.03.01. software was used for the analysis. Analytes were separated using a Zorbax Eclipse XDBC18 $4.6 \mathrm{~mm} \times 50 \mathrm{~mm} \times 1.8 \mu \mathrm{m}$ (Agilent Technologies) reversed-phase column.

\section{Antioxidant activity}

Antioxidant potential was determined using $\mathrm{DPPH} \bullet$ scavenging activity and lipid peroxidation (LP) inhibition assay. Plant extracts were tested for DPPH radical scavenging activity according to (Soler-Rivas, Espín \& Wichers, 2000). The ability of extracts to inhibit lipid peroxidation was evaluated by the spectrophotometric TBA assay (Aust, 1985). Linseed oil obtained from linseed by hexane extraction was used as a source of polyunsaturated fatty acids (69.7\% linolenic, $13.5 \%$ linoleic acid, as determined by GC-MS). The results are expressed as IC50 values.

\section{Statistical analyses}

The obtained data were expressed as mean \pm standard deviation (SD) of three independent replicates per locality. The analysis of variance (ANOVA) was used to determine any statistically significant differences among means, which is followed by multiple comparison test, Fisher's LSD post hoc test at $\mathrm{P} \leq 0.05$. Means followed by the same letter are not significantly different. Data visualization was performed by BoxPlotR (http://shiny.chemgrid.org/boxplotr/). Lines on the boxplot depict the sample median. Crosses indicate sample means, while whiskers extend to the minimum and maximum values $(R$ Core Team, 2016). Multivariate PCA was conducted based on a correlation matrix with previously scaled and centred values in the dataset (R Core Team, 2016) using the following packages: ade4 (http://pbil.univ-lyon1.fr/ADE4), vegan (https://github.com/vegandevs/vegan) and factoextra.

\section{RESULTS}

The analysis of total arsenic content in all analysed samples showed variation among the plant samples, as well as among the place of vegetables growing (Table 1). The lowest average of As content was recorded in parsley roots, followed by celery root and parsley leaves, while the highest As concentration was measured in celery leaves $(0.16 \mu \mathrm{g} / \mathrm{g}$ d.m. $<0.19$ $\mu \mathrm{g} / \mathrm{g}$ d.m. $<0.35 \mu \mathrm{g} / \mathrm{g}$ d.m. $<0.45 \mu \mathrm{g} / \mathrm{g}$ d.m. respectively). The lowest recorded concentration of arsenic in parsley roots was $0.06 \mu \mathrm{g} / \mathrm{g}$ d.m., whereas an extremely high concentration indicating As-contamination $(0.38 \mu \mathrm{g} / \mathrm{g}$ d.m.) was registered in the root tissue of parsley cultivated on soil near the urban zone (Table 1). The results of the chemical analysis carried out on the parsley leaf showed significant variation among localities (Table 1), where only samples taken from Pivnice locality showed As content of $0.17 \mu \mathrm{g} / \mathrm{g}$ d.m. When it comes to celery leaves, all samples showed the presence of As content in dry plant material, regardless of the growing locality. Interestingly, the highest concentration of As detected in this study (0.99 $\mu \mathrm{g} / \mathrm{g}$ ) was obtained in celery leaves taken from the Pivnice site the same site with the lowest As content in parsley leaves.

In parsley root total phenolic content (TPC) ranged from 5.03 to $9.18 \mathrm{mg}$ eq GA/g DE (Fig. 2A) whereas total flavonoid content (TFC) ranged from 0.70 to $1.54 \mathrm{mg}$ eq quercetin/g DE (Fig. 2C). Phenolics were represented by phenylpropanoids, flavonoids and coumarins (Table 2). Among phenylpropanoids chlorogenic acid and several cinnamic acids dominated. The most abundant were ferulic acid which ranged from 2.83 to $41.01 \mu \mathrm{g} / \mathrm{g}$ and chlorogenic acid which varied from $<1.2 \mu \mathrm{g} / \mathrm{g}$ to $49.33 \mu \mathrm{g} / \mathrm{g}$. Apigenin and its glucosides dominated among flavonoids in the parsley root (Table 2B). Apigenin ranged from 0.74 to 3.15 $\mu \mathrm{g} / \mathrm{g}$. A similar trend was identified in apigenin 7-O-glucoside which varied from 1.03 to 4.37 $\mu \mathrm{g} / \mathrm{g}$. Apiin was most abundant flavonoid ranging from 1862 to $3100 \mu \mathrm{g} / \mathrm{g}$. Parsley roots from Ruma and Futog had the lowest amount of coumarins, whereas the highest was in samples from Nakovo and Debeljača (Table 2C). The most abundant coumarin was scopoletin which varied from 0.74 to $42.82 \mu \mathrm{g} / \mathrm{g}$. In celery roots TPC ranged from 5.04 to $8.50 \mathrm{mg}$ eq GA/g DE (Fig. 2B), while varied from 0.35 to $1.05 \mathrm{mg}$ eq quercetin/g DE (Fig. 2D). 
Slobodanka P. Pajević et al., Arsenic content and phenolic compounds in parsley (Petroselinum crispum (Mill.) Fuss) and celery (Apium graveolens L.) cultivated in Vojvodina region, Serbia, Food and Feed Research, 48 (2), 213-225, 2021

Table 1.

Arsenic concentration $(\mu \mathrm{g} / \mathrm{g})$ in parsley and celery grown at various localities. Values are presented as mean \pm standard deviation $(\mathrm{n}=3$ per each locality). ANOVA test was performed per each plant species and organ, separately, following by post hoc Tukey test at $p<0.05$, where different letters indicate statistically significant differences among localities within each plant tissue

\section{Arsenic concentration}

$(\mu \mathrm{g} / \mathrm{g})$

\begin{tabular}{llll}
\hline Locality & Parsley roots & Locality & Parsley leaves \\
\hline Mol & $0.09 \pm 0.02 \mathrm{~cd}$ & Mol & $0.35 \pm 0.04 \mathrm{ab}$ \\
Donji Petrovci & $0.08 \pm 0.01 \mathrm{~cd}$ & Donji Petrovci & $0.25 \pm 0.03 \mathrm{ab}$ \\
Debeljača & $0.22 \pm 0.05 \mathrm{~b}$ & Kikinda & $0.46 \pm 0.01 \mathrm{a}$ \\
Kikinda & $0.12 \pm 0.03 \mathrm{bcd}$ & Nakovo & $0.34 \pm 0.01 \mathrm{ab}$ \\
Nakovo & $0.18 \pm 0.03 \mathrm{bc}$ & Ruma & $0.34 \pm 0.14 \mathrm{ab}$ \\
Ruma & $0.06 \pm 0.01 \mathrm{~d}$ & Futog & $0.47 \pm 0.12 \mathrm{a}$ \\
Futog & $0.38 \pm 0.02 \mathrm{a}$ & Pivnice & $0.17 \pm 0.01 \mathrm{~b}$ \\
& & Kisač & $0.43 \pm 0.07 \mathrm{ab}$ \\
\hline Mean $\pm S D$ & $0.16 \pm 0.10$ & Mean $\pm S D$ & $0.35 \pm 0.12$ \\
\hline & & & Celery leaves \\
\hline Locality & Celery roots & Locality & $0.48 \pm 0.02 \mathrm{~b}$ \\
\hline Mol & $0.09 \pm 0.02 \mathrm{~b}$ & Mol & $0.25 \pm 0.01 \mathrm{c}$ \\
Donji Petrovci & $0.16 \pm 0.01 \mathrm{~b}$ & Kikinda & $0.28 \pm 0.05 \mathrm{c}$ \\
Kikinda & $0.1 \pm 0.01 \mathrm{~b}$ & Nakovo & $0.25 \pm 0.02 \mathrm{c}$ \\
Nakovo & $0.06 \pm 0.02 \mathrm{~b}$ & Ruma & $0.99 \pm 0.08 \mathrm{a}$ \\
Ruma & $0.11 \pm 0.01 \mathrm{~b}$ & Pivnice & \\
Pivnice & $0.51 \pm 0.2 \mathrm{a}$ & & $0.45 \pm 0.28$ \\
Apatin & $0.11 \pm 0.03 \mathrm{~b}$ & & \\
\hline Mean $\pm S D$ & $0.19 \pm 0.17$ & Mean $\pm S D$ & \\
\hline
\end{tabular}
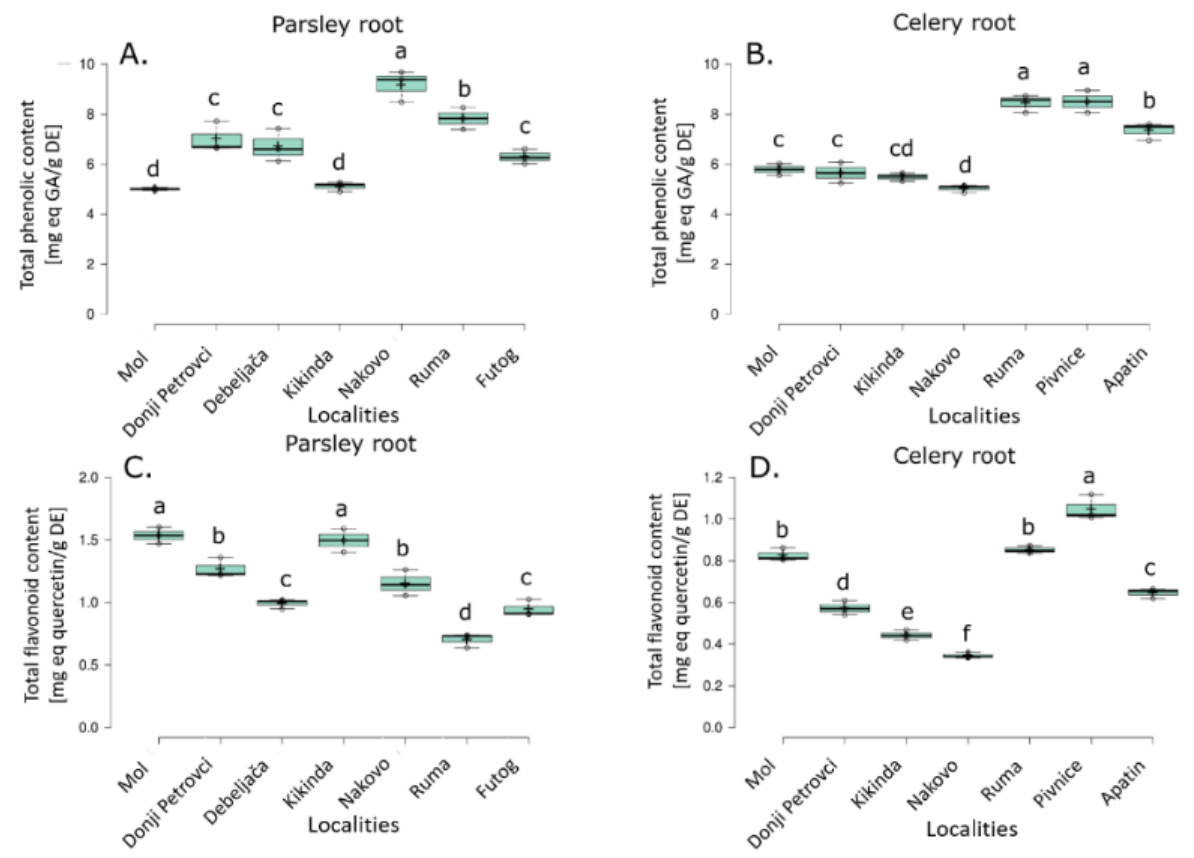

Figure 2. Total phenolic content (mg eq GA/g DE) in parsley root (A) and celery root (B); Total flavonoid content $(\mathrm{mg}$ eq quercetin/g DE) in parsley root $(\mathbf{C})$ and celery root $(\mathbf{D})$

Among phenolic acids, ferulic and chlorogenic acid dominated (Table 3A). The content of ferulic acid ranged from 9.49 to $29.89 \mu \mathrm{g} / \mathrm{g}$ and chlorogenic acid from below the limit of quan- titation (LoQ) to $41.15 \mu \mathrm{g} / \mathrm{g}$. Among flavonoids, apigenin and luteolin aglycons and glucosides were identified (Table 3B). Apigenin varied from 0.43 to 4.01 , apigenin-7-O-glucoside ran- 
ged from 0.31 to $2.32 \mu \mathrm{g} / \mathrm{g}$ (Apatin), luteolin-7$O$-glucoside varied from LoQ to $6.17 \mu \mathrm{g} / \mathrm{g}$. Apiin was the most abundant flavonoid ranging from 82.11 to $881.80 \mu \mathrm{g} / \mathrm{g}$. Umbelli-feron was a major coumarin ranging from 1.55 to 108.00 $\mu \mathrm{g} / \mathrm{g}$ (Table 3C). The content of scopoletin ranged from 5.08 to $57.21 \mu \mathrm{g} / \mathrm{g}$.

The antioxidant capacity of parsley and celery root extracts were evaluated by measuring DPPH-radical scavenging capacity (DPPHRSC) (Fig. 3A; 3B) and ability to inhibit lipid peroxidation (LP) (Fig. 3C; 3D) and they are expressed as IC50 values $(\mathrm{mg} / \mathrm{mL})$. Obtained results indicate mild to moderate antioxidant activity in both parsley and celery roots, but the differences were significant depending on the cultivation site. The mean value of IC50 (DPPH-RSC) for all samples of parsley roots was $0.62 \pm 0.16 \mathrm{mg} / \mathrm{mL}$ (Fig. 3A). In celery roots, slightly higher DPPH-RSC (IC50 mean value $0.44 \pm 0.07 \mathrm{mg} / \mathrm{mL}$ ) values were obtained in comparison to parsley roots (Fig. 3B). Parsley and celery exhibited similar LP inhibition activities, IC50 (average values of 2.34 and 2.23 $\mathrm{mg} / \mathrm{mL}$, respectively). The highest LP inhibition was found in celery root (IC50 $1.21 \mathrm{mg} / \mathrm{mL}$, Pivnice locality) (Fig. 3D) and the lowest in parsley root from Ruma (IC50 $3.40 \mathrm{mg} / \mathrm{g}$ d.e.) (Fig. 3C).

The results of all investigated parameters were run over a multivariate PCA and shown in Fig. 4. The effect of the examined traits at the species level points to differences between the analysed samples (Fig. 4A; 4B). The majority of variance is weighted in the first three components $(56.1 \%)$, with api-7-O-Glc, apiin, flavonoids, DPPH, p-coum, caf, cimm, aesc as key determinants for such clustering. Fig. 4C shows the differences in the parsley samples collected from different localities.

Table 2.

Phenolic compounds content in parsley root ${ }^{*}(\mu \mathrm{g} / \mathrm{g}$ dry extract)

\begin{tabular}{|c|c|c|c|c|c|c|c|}
\hline Localities & Mol & $\begin{array}{c}\text { Donji } \\
\text { Petrovci }\end{array}$ & Debeljača & Kikinda & Nakovo & Ruma & Futog \\
\hline \multicolumn{8}{|l|}{ A. Phenolic acids } \\
\hline $\begin{array}{l}p \text {-OH-Benzoic } \\
\text { acid }\end{array}$ & $<2.4$ & $<2.4$ & $<2.4$ & $<2.4$ & $<2.4$ & $<2.4$ & $<2.4$ \\
\hline Cinnamic acid & $1.42 \pm 0.2$ & $2.43 \pm 0.5$ & $2.68 \pm 0.5$ & $2.18 \pm 0.4$ & $5.92 \pm 1.2$ & $2.37 \pm 0.5$ & $1.55 \pm 0.3$ \\
\hline $\begin{array}{l}\text { Protocatechuic } \\
\text { acid }\end{array}$ & $0.31 \pm 0.1$ & $2.35 \pm 0.2$ & $2.08 \pm 0.2$ & $1.79 \pm 0.1$ & $1.39 \pm 0.1$ & $5.36 \pm 0.4$ & $1.47 \pm 0.1$ \\
\hline $\begin{array}{l}\text { 2,5-Dihydroxy } \\
\text { benzoic acid }\end{array}$ & $<2.4$ & $2.67 \pm 0.5$ & $<2.4$ & $3.58 \pm 0.7$ & $4.30 \pm 0.9$ & $2.58 \pm 0.5$ & $3.49 \pm 0.7$ \\
\hline $\begin{array}{l}p \text {-Coumaric } \\
\text { acid }\end{array}$ & $2.36 \pm 0.1$ & $1.50 \pm 0.1$ & $1.70 \pm 0.1$ & $1.45 \pm 0.1$ & $2.47 \pm 0.2$ & $0.61 \pm 0.1$ & $1.10 \pm 0.1$ \\
\hline Caffeic acid & $2.34 \pm 0.2$ & $3.41 \pm 0.2$ & $3.27 \pm 0.2$ & $2.83 \pm 0.2$ & $3.20 \pm 0.2$ & $<2$ & $2.17 \pm 0.1$ \\
\hline Ferulic acid & $13.48 \pm 1.3$ & $15.80 \pm 1$ & $41.01 \pm 4.1$ & $11.82 \pm 1.2$ & $41.14 \pm 4.1$ & $2.83 \pm 0.3$ & $9.37 \pm 0.9$ \\
\hline $\begin{array}{l}\text { Chlorogenic } \\
\text { acid }\end{array}$ & $9.82 \pm 0.5$ & $27.34 \pm 1$ & $49.33 \pm 2.5$ & $9.36 \pm 0.5$ & $20.20 \pm 1.0$ & $<1.2$ & $6.07 \pm 0.3$ \\
\hline \multicolumn{8}{|l|}{ B. Flavonoids } \\
\hline Apigenin & $0.74 \pm 0.05$ & $3.15 \pm 0.22$ & $2.31 \pm 0.16$ & $2.64 \pm 0.18$ & $1.16 \pm 0.08$ & $1.83 \pm 0.13$ & $1.51 \pm 0.11$ \\
\hline $\begin{array}{l}\text { Apigenin-7-O- } \\
\text { glucoside }\end{array}$ & $1.03 \pm 0.05$ & $4.37 \pm 0.22$ & $2.21 \pm 0.11$ & $2.77 \pm 0.14$ & $1.12 \pm 0.06$ & $2.26 \pm 0.11$ & $2.77 \pm 0.14$ \\
\hline $\begin{array}{l}\text { Luteolin } \quad 7-O- \\
\text { glucoside }\end{array}$ & $<0.6$ & $<0.6$ & $<0.6$ & $<0.6$ & $<0.6$ & $<0.6$ & $<0.6$ \\
\hline Chrysoeriol & $<0.08$ & $0.13 \pm 0.01$ & $<0.08$ & $<0.08$ & $<0.08$ & $<0.08$ & $0.08 \pm 0.01$ \\
\hline Apiin & $2353 \pm 117$ & $1862 \pm 93$ & $3100 \pm 155$ & $2124 \pm 106$ & $2221 \pm 111$ & $2266 \pm 113$ & $2615 \pm 130$ \\
\hline \multicolumn{8}{|l|}{ C. Coumarins } \\
\hline Umbelliferon & $0.72 \pm 0.07$ & $0.56 \pm 0.06$ & $2.41 \pm 0.24$ & $0.42 \pm 0.04$ & $2.34 \pm 0.23$ & $<0.3$ & $<0.3$ \\
\hline Esculetin & $<0.3$ & $0.36 \pm 0.02$ & $0.84 \pm 0.05$ & $<0.3$ & $0.81 \pm 0.05$ & $<0.3$ & $<0.3$ \\
\hline Scopoletin & $20.34 \pm 1.6$ & $9.55 \pm 0.7$ & $42.82 \pm 3.4$ & $10.38 \pm 0.8$ & $198.4 \pm 15.9$ & $2.88 \pm 0.2$ & $0.74 \pm 0.1$ \\
\hline
\end{tabular}



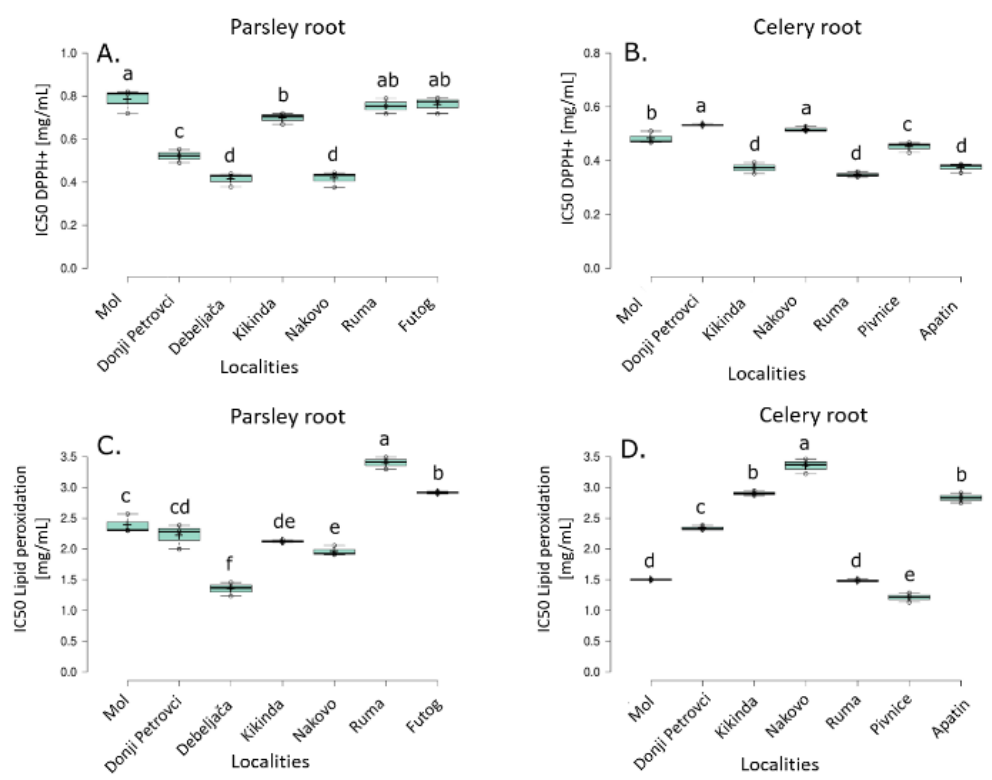

Figure 3. Antioxidant potential: DPPH` scavenging activity $(\mathrm{mg} / \mathrm{mL})$ in parsley root $(\mathbf{A})$ and celery $\operatorname{root}(\mathbf{B})$; Lipid peroxidation $(\mathrm{mg} / \mathrm{mL})$ in parsley root $(\mathbf{C})$ and celery root $(\mathbf{D})$

Table 3.

Phenolic compounds content in celery root* $(\mu \mathrm{g} / \mathrm{g}$ dry extract)

\begin{tabular}{|c|c|c|c|c|c|c|c|}
\hline Localities & Mol & $\begin{array}{l}\text { Donji } \\
\text { Petrovci }\end{array}$ & Kikinda & Nakovo & Ruma & Pivnice & Apatin \\
\hline \multicolumn{8}{|l|}{ A. Phenolic acids } \\
\hline $\begin{array}{l}p \text {-OH-Benzoic } \\
\text { acid }\end{array}$ & $<2.4$ & $<2.4$ & $<2.4$ & $<2.4$ & $3.17 \pm 0.19$ & $<2.4$ & $<2.4$ \\
\hline Cinnamic acid & $<2.5$ & $3.58 \pm 0.72$ & $9.76 \pm 1.95$ & $2.68 \pm 0.54$ & $<2.5$ & $<2.5$ & $2.62 \pm 0.52$ \\
\hline $\begin{array}{l}\text { Protocatechuic } \\
\text { acid }\end{array}$ & $0.71 \pm 0.06$ & $1.06 \pm 0.08$ & $1.01 \pm 0.08$ & $0.96 \pm 0.08$ & $<0.5$ & $0.76 \pm 0.06$ & $<0.5$ \\
\hline $\begin{array}{l}\text { 2,5-Dihydroxy } \\
\text { benzoic acid }\end{array}$ & $1.69 \pm 0.34$ & $1.35 \pm 0.27$ & $0.95 \pm 0.19$ & $1.11 \pm 0.22$ & $2.40 \pm 0.48$ & $0.78 \pm 0.16$ & $1.20 \pm 0.24$ \\
\hline $\begin{array}{l}p \text {-Coumaric } \\
\text { acid }\end{array}$ & $<1$ & $<1$ & $<1$ & $<1$ & $<1$ & $<1$ & $<1$ \\
\hline Caffeic acid & $2.30 \pm 0.16$ & $2.34 \pm 0.16$ & $3.99 \pm 0.28$ & $2.74 \pm 0.19$ & $<2$ & $<2$ & $2.64 \pm 0.18$ \\
\hline Ferulic acid & $18.28 \pm 1.8$ & $28.44 \pm 2.8$ & $10.69 \pm 1.1$ & $11.74 \pm 1.8$ & $9.49 \pm 0.95$ & $15.44 \pm 1.5$ & $29.89 \pm 2.9$ \\
\hline $\begin{array}{l}\text { Chlorogenic } \\
\text { acid }\end{array}$ & $6.99 \pm 0.35$ & $11.63 \pm 0.6$ & $41.15 \pm 2.0$ & $15.94 \pm 0.8$ & $<1.2$ & $9.14 \pm 0.45$ & $4.82 \pm 0.24$ \\
\hline \multicolumn{8}{|l|}{ B. Flavonoids } \\
\hline Apigenin & $0.88 \pm 0.06$ & $0.84 \pm 0.06$ & $0.25 \pm 0.02$ & $0.43 \pm 0.03$ & $4.01 \pm 0.28$ & $1.75 \pm 0.12$ & $3.49 \pm 0.24$ \\
\hline $\begin{array}{l}\text { Apigenin-7-O- } \\
\text { glucoside }\end{array}$ & $0.70 \pm 0.03$ & $1.03 \pm 0.05$ & $0.31 \pm 0.02$ & $0.32 \pm 0.02$ & $1.83 \pm 0.09$ & $0.80 \pm 0.04$ & $2.32 \pm 0.12$ \\
\hline $\begin{array}{l}\text { Luteolin } \\
\text { glucoside }\end{array}$ & $<0.6$ & $2.04 \pm 0.06$ & $6.17 \pm 0.18$ & $0.66 \pm 0.02$ & $<0.6$ & $1.05 \pm 0.03$ & $2.01 \pm 0.06$ \\
\hline Chrysoeriol & $0.19 \pm 0.01$ & $0.18 \pm 0.01$ & $0.46 \pm 0.01$ & $0.20 \pm 0.01$ & $2.01 \pm 0.06$ & $1.09 \pm 0.03$ & $0.72 \pm 0.02$ \\
\hline Apiin & $564.1 \pm 28.2$ & $881.8 \pm 44.1$ & $82.11 \pm 4.1$ & $186.2 \pm 9.3$ & $741.9 \pm 37.1$ & $804.1 \pm 40$ & $738.9 \pm 36.9$ \\
\hline \multicolumn{8}{|l|}{ C. Coumarins } \\
\hline Umbelliferon & $108.0 \pm 10.8$ & $60.84 \pm 6.1$ & $13.53 \pm 1.3$ & $8.19 \pm 0.8$ & $1.55 \pm 0.15$ & $70.98 \pm 7.1$ & $2.98 \pm 0.29$ \\
\hline Esculetin & $0.76 \pm 0.05$ & $0.37 \pm 0.02$ & $1.06 \pm 0.06$ & $1.13 \pm 0.07$ & $<0.2$ & $0.35 \pm 0.02$ & $0.34 \pm 0.02$ \\
\hline Scopoletin & $12.80 \pm 1.03$ & $13.52 \pm 1.1$ & $55.29 \pm 4.4$ & $41.19 \pm 3.3$ & $9.67 \pm 0.77$ & $57.21 \pm 4.6$ & $5.08 \pm 0.41$ \\
\hline
\end{tabular}

Values in tables are expressed as mean \pm standard deviation $(n=3)$.

*Analysed concentration is lower than the limit of detection: o-coumaric acid, vanillic acid, gallic acid, syringic acid, 3,4dimethoxycinnamic acid, synaptic acid, daidzein, genistein, kaempferol, catechin, epicatechin, quercetin, isorhamnetin, myricetin, matairesinol, secoisolariciresinol, vitexin, baicalin, quercitrin, kaempferol-3-O- glucoside, epigallocatechin gallate, hiperoside, amentoflavone, rutin, quercetin-3-O-glucoside, baicalein, luteolin, naringenin 
A.

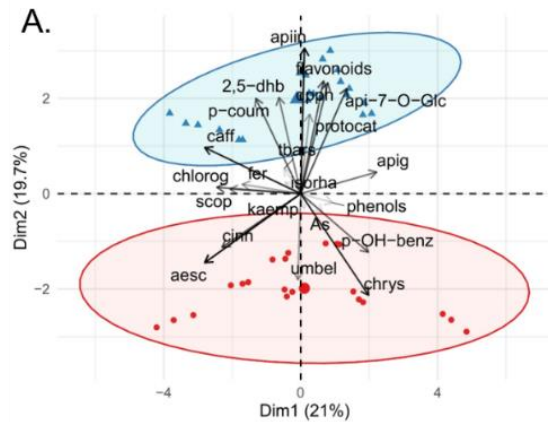

C.
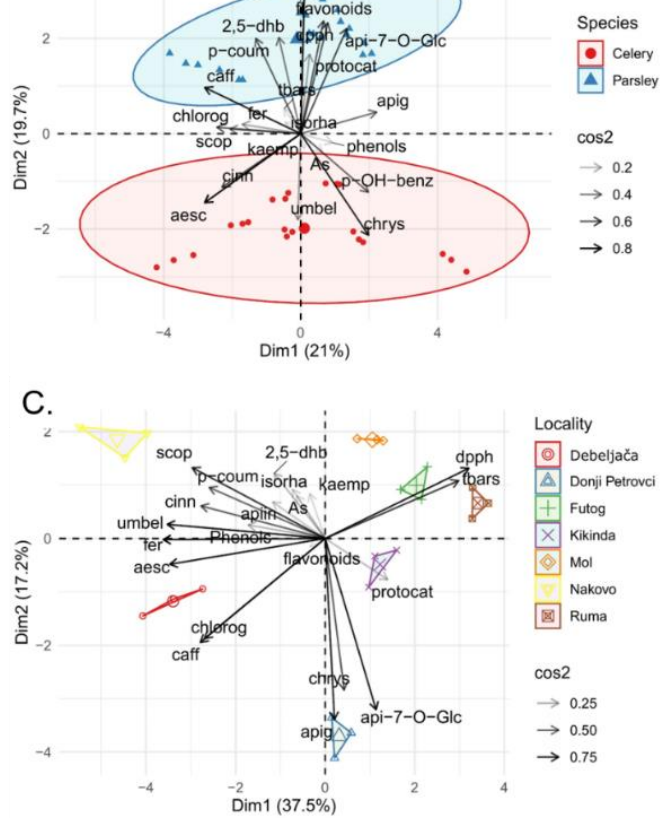

B.

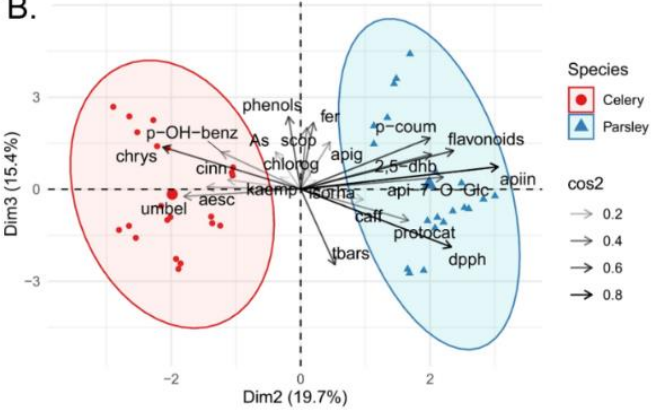

D.

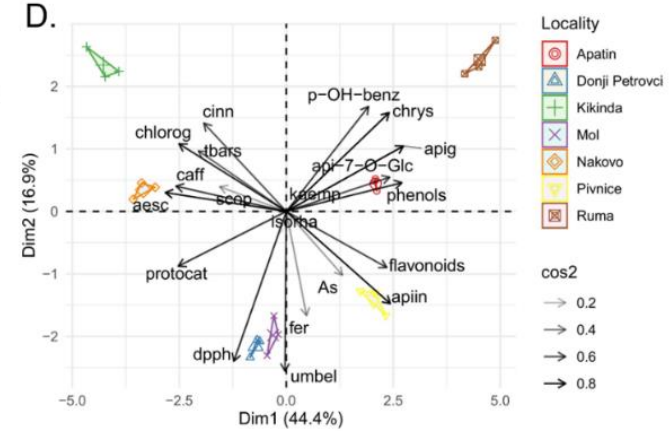

Figure 4. Multivariate analysis of tested metabolites, arsenic content and radical scavenging assay. A biplot of tested species in the first two principal component (PC), where ellipses on biplot assumes multivariate normal distribution (A); Biplot of tested species in the second and third examined dimensions (PC) (B); Biplot of parsley samples from different localities (C); Biplot of celery samples from different localities (D). Cos 2 value is the square loadings for variables, presenting the quality of the representation of variables. Dim1 and Dim2 corresponds to the first and second principal components

Variable symbols legend: 2,5-dhb - 2,5-dihydroxybenzoic acid; aesc - aesculetin; apiin - apiin; apig - apigenin; api-7-O-Glc - api-7-O-Glc; As - arsenic concentration; caff - caffeic acid; cinn - cinnamic acid; chlorog - chlorogenic acid; chrys chrysoeriol; dpph - DPPH; ferr - ferulic acid; flavonoids - flavonoid content; isorha - isorhamnetin; kaemp - kaempferol; pcoum - p-coumaric acid; phenols - phenolic content; p-OH-benz - p-OH-benzoic acid; protocat - protocatechuic acid; scop scopoletin; tbars - lipid peroxidation; umbel - umbelliferon

The sampling site has a clear significant impact on the metabolites profile since we can cluster them in two different groups by both first (37.5\% of variation) and a second component $(17.2 \%)$. In the first component, variables umbel, fer and aesc are major contributors for clustering the samples originating from Debeljača and Nakovo opposite the rest of the localities on the biplot.

The clustering across the second component is mostly due to the contents of apig, chrys and api-7-O-Glc. It should also be noted that the arsenic contents contributed to the separation of the samples across the biplot. The celery samples were similar to the parsley ones, distinctly clustered over the biplot (Fig. 4D). The overall variation of the first two principal components is $61.3 \%$. The content of aesc, caff, protocat, phenols and api-7-O-Glc are separating localities over the first principal component. The contents of umbelliferon and ferulic acid are highly correlated with the second PC and are thus the main variables that separate the localities in this dimension.

\section{DISCUSSION}

According to international standards for contaminants and toxins in food, adopted by the World Health Organization (WHO) and the Food and Agriculture Organization of the United Nations (FAO/WHO, 2015) the maximum permissible concentrations of total As are indicated for oils and fats in the diet as 0.1 $\mathrm{mg} / \mathrm{kg}$, for polished rice as $0.2 \mathrm{mg} / \mathrm{kg}$, and the means of packaging, transport and disposal as $0.5 \mathrm{mg} / \mathrm{kg}$. However, the maximum permissible concentrations of As in vegetables and fruits are not defined in the WHO and FAO Regulations. Considering the number of plants used in animal and human diet, it is important to define species that are not hyperaccumulators, or at least ones that do not accumulate toxic amounts of arsenic in edible parts. Therefore, the meta- 
bolism and redistribution of As in plant (cell) organs are essential indicators of food quality.

Numerous studies have shown a significant correlation between As concentration in various plant species and the chemical composition of the soil solution (Finnegan \& Chen, 2012; McBride, Shayler, Russell-Anelli, Spliethoff \& Marquez-Bravo, 2015; Arsenov et al., 2021b). Also, many data indicating that vegetables sold on green markets contain significant amounts of different heavy metals, which often exceed the permissible limits set by the environmental protecttion administrations and institutions (Nikolić et al., 2014; Pan, Wu \& Jiang et al. 2016; Pajević et al., 2018; Rusin, Domagalska, Rogala, Razzaghi \& Szymala, 2021).

Since parsley and celery are known as vegetables frequently used in the human diet, as well as favourite spices rich in B vitamins, vitamin $\mathrm{C}, \beta$-carotene and many minerals (Farzaei, Abbasabadi, Rahimi \& Farzaei, 2013), its contamination with toxic substances can significantly impair its quality. Additionally, parsley and celery can be defined as medicinal herbs, since they possess proven therapeutic purposes for human wellbeing, and therefore they can be used in traditional or officinal medicine (Odobasic, Sestan \& Bratovcic, 2017). Potential of medicinal plants for As accumulation was previously reported by Pyne and Santra (2017), authors showed that arsenic concentrations in medicinal plants varied from $0.027 \mathrm{mg} / \mathrm{kg}$ to $0.298 \mathrm{mg} / \mathrm{kg}$ of dry plant weight. Similarly, we have recorded significantly high variability in As content between species, plant organs among analysed localities, where the possible reasons can be a consequence of geological specificity, applied agro-technical measures, as well as the vicinity of As pollution industry. Dahal et al. (2008) showed that the As content in different parts of edible plants grown on moderately polluted soils was found in the range from 0.01 $\mathrm{mg} / \mathrm{kg}$ to $0.55 \mathrm{mg} / \mathrm{kg}$ of dry plant weight, with the concentration gradient concerning plant organ as follows: root >stem > leaf > edible part of the plant. In general, the highest arsenic accumulation is often recorded in root tissue, which is the consequence of As impact on root-cells metabolism and slow transport to the aboveground plant parts (Gupta et al., 2008).

Phenolic compounds can greatly contribute to plant antioxidant activity, however, their level and accumulation in plant tissue can be in- fluenced by different abiotic and biotic factors (Hasanuzzaman et al., 2020). Parsley extracts (roots and leaves) were shown to possess both in vitro and in vivo free radical scavenging activity, capable of reducing lipid peroxidation and moderating some enzymes of antioxidant defence systems (Popović, Kaurinović, Jakovljević, Mimica-Dukić \& Bursać, 2007). Parsley and celery are known as species with many beneficial effects on human health since they possess diuretic, antidiabetic, anti-hyperglycemic, antipyretic and antimicrobial activity (Farzaei, Abbasabadi, Rahimi \& Farzaei, 2013). Celery is known to possess antirheumatic properties and can be used in curing arthritis, rheumatism, gout, bladder and kidney complaints (Bisset \& Wichtl, 1994). Also, it is known that celery possesses a high content of polyphenolics in leaves, which have high therapeutic potential (PerezGutierre, Muniz-Ramirez, Campoy, Flores \& Flores, 2018). The authors detected apigenin, kaempferol, apiin, rutin, caffeic acid, ferulic acid, chlorogenic acid and p-coumaric acid as major compounds in methanol plant extracts and demonstrated that this extract has an excellent anti-glycation effect. The results of our study showed great variability in the quantitative composition of identified phenolics between samples depending on the growing localities, which was evident in both analysed species. Our TPC results were similar to those previously published by Popova et al. (2014). The authors reported that TPC in celery roots extract was around $8 \mathrm{mg} \mathrm{eqGA} / \mathrm{g} \mathrm{DE}$, half as much as in their corresponding leaves. The same authors reported that TFC in celery samples ranged from 1-4.8 mg Q/g DE, which is higher in comparison to the results obtained in this study. On contrary, Stankevićius et al. (2011) found fewer amounts of TPC in celery roots in comparison to our results.

Most relevant literature data reports that flavone glycosides, mostly those of apigenin are major flavonoids that occurred in parsley (Agyare, Appiah \& Apenteng, 2017) while kaempferol, genkwanin and quercetin glycosides were major phenolic compounds in celery roots (Nikolić, Cvetković \& Todorović, 2011). Results of our study revealed that celery root extracts were rich in apigenin and apiin, as major flavonoids. Apigenin was found to possess remarkable biological and health-promoting activity, while apiin is recognized as a remarkably strong antioxidant and anti-inflammatory agent (Peng et al., 2004; Mencherini et al., 2007). Besides the 
already reported furanocoumarins in parsley and celery: psoralen, imperatorin, pimpinellin and isopimpinellin, bergapten (Mimica-Dukić \& Popović, 2007) in this research we have found significant amounts of umbelliferon, and scopoletin in both plant species. There is a huge number of publications dealing with antioxidant activities of parsley and celery roots, leaves, seeds etc. (Mimica-Dukić \& Popović, 2007; Agyare, Appiah \& Apenteng, 2017; Arsenov et al., 2021a). The naturally present apiin from celery is known as flavonoid which can exhibit high total antioxidant activity (TAOC) and promote the activity of antioxidant enzymes to provide additional protection for the heart, liver and kidney (Peng et al., 2004). Additionally, Cd accumulation in parsley seedlings can have a significant influence on TPC amounts, ferric reduction potential, SOD and DPPH free radical scavenging activities (Ulusu, Ozturk \& Elmastas, 2017).

Based on PCA in parsley dataset, it is shown that flavonoid components apiin, apigenin-7-Oglucoside and chrysoeriol vary by major factors for dividing localities into three groups over 2 nd PC. Coumarins with phenolics (ferulic and caffeic acid) are grouping our samples in two distinct clusters. Regarding overall phenolics compound contents, we can indicate samples from four localities (Futog, Ruma, Kikinda, and Mol) as very poor. Celery dataset PC analysis output is showing a diversification in samples phenolic compounds contents. High content of ferulic acid and umbelliferon in celery samples from two localities are probably the cause of higher radical scavenging activity assayed with the DPPH test. Various contents of phenolic acids and coumarins components are the cause of samples diversification in 1st PC. Considering the cultivation site, we can say that celery samples are almost equally loaded with particular phenolic compounds, thus we cannot exclude any of them as significantly poor or rich from others. According to overall data, we can conclude that measured arsenic concentrations in investigated vegetables did not significantly affect phenolic compound profiles.

\section{CONCLUSIONS}

Significant variations in As content was obtained depending on plant species, plant organs and geographical origin. The increasing range of As concentration in the examined vegetables can be presented as parsley root $<$ celery root $<$ parsley leaf < celery leaf, where the accumulation of As in the leaves was almost twice as high as in the root tissue. Great variability in the quantitative composition of identified phenolics between samples was recorded in both species. This could be the consequence of different cultivation and plant preservation methods. In the plant extracts, apigenin and apiin were the major flavonoids. Obtained results indicate mild to moderate antioxidant activity in both parsley and celery roots, but the differrences were significant depending on the cultivation site. However, according to overall data, based on PCA, we can conclude that measured arsenic concentrations in investigated vegetables did not significantly affect phenolic compound profiles.

\section{ACKNOWLEDGEMENTS}

The research was conducted and funded within the project entitled: "Biologically active components and medical potential of functional food grown in Vojvodina Province, Serbia" no. 114451-2149/2016-03, financed by the Provincial Secretariat for Science and Technological Development, Autonomous Province of Vojvodina, Serbia. The authors acknowledge the financial support of the Ministry of Education, Science and Technological Development of the Republic of Serbia (Grant No. 451-03-9/202114/200125).

\section{REFERENCES}

Agyare, C., Appiah, Y. D. B., \& Apenteng, J. A. (2017) Petroselinum crispum: a review. In V. Kuete (Ed.), Medicinal species and vegetable from Africa (pp. 527-547). Cambridge, UK: Academic Press.

Arsenov, D., Župunski, M., Pajević, S., Nemeš, I., Simin, N., Alnuqaydan, A. M., Watson, M., Aloliqi, A. A., \& Mimica-Dukić, N. (2021a). Roots of Apium graveolens and Petroselinum crispumInsight into phenolic status against toxicity level of trace elements. Plants, 10(9), Article1785. https://doi.org/10.3390/plants10091785

Arsenov, D., Župunski, M., Pajević, S., Borišev, M., Nikolić, N., \& Mimica-Dukić N. (2021b). Health assessment of medicinal herbs, celery and parsley related to cadmium soil pollutionpotentially toxic elements (PTEs) accumulation, tolerance capacity and antioxidative response. Environmental Geochemistry and Health, 43, 2927-2943. https://doi.org/10.1007/s10653-02000805-x

Aust, S. D. (1985). Lipid peroxidation. In R. A. Greenwald (Ed.), Handbook of methods for oxygen radical research (pp. 203-207). Boca Raton Florida: CRC Press. 
Beara, I. N., Lesjak, M. M., Orčić, D. Z., Simin, N. Đ., Četojević-Simin, D. D., Božin, B. N., \& MimicaDukić, N. M. (2012). Comparative analysis of phenolic profile, antioxidant, anti-inflammatory and cytotoxic activity of two closely-related Plantain species: Plantago altissima L. and Plantago lanceolata L. LWT Food Science and Technology, 47(1), 64-70. https://doi.org/10.1016/j.lwt.2012.01.001

Bencko, V., \& Foong, F. Y. L. (2017). The history of arsenical pesticides and health risks related to the use of Agent Blue. Annals of Agricultural and Environmental Medicine, 24(2), 312-316. https://doi.org/10.26444/aaem/74715

Bhattacharya, P., Samal, A. C., Majumdar, J., \& Santra, S. C. (2010). Arsenic contamination in rice, wheat, pulses, and vegetables: a study in an arsenic affected area of west Bengal, India. Water Air and Soil Pollution, 213, 3-13. https://doi.org/10.1007/s11270-010-0361-9

Bisset, N. G., \& Wichtl, M. (1994). Herbal drugs and phytopharmaceuticals. Stuttgart: Medpharm GmbH Scientific Publishers, CRC Press.

Chang, C. C., Yang, M. H., Wen, H. M., \& Chern, J. C. (2002). Estimation of total flavonoid content in propolis by two complementary colorimetric methods. Journal of Food and Drug Analysis, 10, 178-182.

Cvejić Hogervorst, J., Russo, G., Godos, J., MimicaDukić, N., Simin, N., Bjelica, A., \& Grosso, G. (2018). Beneficial effects of polyphenols on chronic diseases and ageing. In C. M. Galanakis (Ed.), Polyphenols: properties, recovery and application (pp. 69-103). Oxford, UK: Elsevier, Woodhead Publishing.

Dahal, B. M., Fuerhacker, M., Mentler, A., Karki, K. B., Shrestha, R. R., \& Blum, W. E. (2008). Arsenic contamination of soils and agricultural plants through irrigation water in Nepal. Environmental Pollution, 155(1), 157-163. https://doi.org/10.1016/j.envpol.2007.10.024

FAO/WHO. (2015). Codex Alimentarius-General standards for contaminants and toxins in food and feed. CODEX STAN 193-1995.

Farzaei, M. H., Abbasabadi, Z., Rahimi, R., \& Farzaei, F. (2013). Parley: a review of ethnopharmacology, phytochemistry and biological activities. Journal of Traditional Chinese Medicine, 33, 815-826.

Finnegan, P. M., \& Chen, W. (2012). Arsenic toxicity: the effects on plant metabolism. Frontiers in Physio$\log y, 3$, Article 182 https://doi.org/10.3389/fphys.2012.00182

Gupta, D. K., Tripathi, R. D., Mishra, S., Srivastava, S., Dwivedi, S., Rai, U. N., Yang, X. E., Huanji, H., \& Inouhe, M. (2008). Arsenic accumulation in root and shoot vis-a-vis its effects on growth and level of phytochelatins in seedlings of Cicer arietinum L. Journal of Environmental Biology, 29(3), 281-286.

Hasanuzzaman, M., Bhuyan, M., Zulfiqar, F., Raza, A., Mohsin, S. M., Mahmud, J. A., Fujita. M., \& Fotopoulos V. (2020). Reactive oxygen species and antioxidant defence in plants under abiotic stress: revisiting the crucial role of a universal defence regulator. Antioxidants, 9(8), 681. https://doi.org/10.3390/antiox908068
Jain, A., Yadav, A., Bozhkov, A. I., Padalko, V. I., \& Flora, S. J. S. (2011). Therapeutic efficacy of silymarin and naringenin in reducing arsenic-induced hepatic damage in young rats. Ecotoxicology and Environmental Safety, 74(4), 607614. https://doi.org/10.1016/j.ecoenv.2010.08.002

Kapaj, S., Peterson, H., Liber, K., \& Bhattacharya, P. (2006). Human health effects from chronic arsenic poisoning - a review. Journal of Environmental Science and Health, Part A, 41(10), 2399-23428. https://doi.org/10.1080/10934520600873571

Kostecka-Gugała, A., \& Latowski, D. (2018). Arsenicinduced oxidative stress in plants. In M. Hasanuzzaman, K. Nahar, \& M. Fujita (Eds.), Mechanisms of arsenic toxicity and tolerance in plants (pp. 79-104). Singapore: Springer.

Liu, W. J., Wood, B. A., Raab, A., McGrath, S. P., Zhao, F. J., \& Feldmann, J. (2010). Complexation of arsenite with phytochelatins reduces arsenite efflux and translocation from roots to shoots. Plant Physiology, 152, 2211-2221. https://doi.org/10.1104/pp.109.150862

McBride, M. B., Shayler, H. A., Russell-Anelli, J. M., Spliethoff, H. M., \& Marquez-Bravo, L. G. (2015). Arsenic and lead uptake by vegetable crops grown on an old orchard site amended with compost. Water Air and Soil Pollution, 226(8), Article 265. https://doi.org/10.1007/s11270-0152529-9

McBride, M. B., \& Spiers, G. (2001). Trace element content of selected fertilizers and dairy manures as determined by ICP-MS. Communications in Soil Science and Plant Analysis, 32, 139-156. https://doi.org/10.1081/CSS-100102999

Mencherini, T., Cau, A., Bianco, G., Della Loggia, R., Aquino, R. P., \& Autore, G. (2007). An extract of Apium graveolens var. dulce leaves: structure of the major constituent, apiin, and its antiinflammatory properties. Journal of Pharmacy and Pharmacology, 59, 891-897.

Michalak, A. (2006). Phenolic compounds and their antioxidant activity in plants growing under heavy metal stress. Polish Journal of Environmental Studies, 15(4), 523-530.

Mimica-Dukić, N., \& Popović, M. (2007). Apiaceae species: a promising source of pharmacologically active compounds I: Petrosellinum crispum, Apium greveolens and Pastinaca sativa. In J. N. Govil, V. K. Singh (Eds.), Recent Progress in Medicinal Plants - Phytopharmacology and Therapeutic Values III (pp. 132-133). Houston: Studim Press LLC.

Mišan, A. (2011). Antioxidant properties of food supplemented with medicinal plants. Food and Feed Research, 37(2), 81-85.

Mollah, M. Y. A., Lu, F., \& Cocke, D. L. (1998). An X-ray diffraction (XRD) and Fourier transform infrared spectroscopic (FT-IR) characterization of the speciation of arsenic (V) in Portland cement type-V. Science of the Total Environment, 224, 57-68. https://doi.org/10.1016/S0048-9697(98)003180

Nikolić, N., Cvetković, D., \& Todorović, Z. (2011). A characterization of content, composition and antioxidant capacity of phenolic compounds in 
celery roots. Italian Journal of Food Science 23(2), 214-219.

Nikolić, N., Borišev, M., Pajević, S., Arsenov, D., \& Župunski, M. (2014). Comparative assessment of mineral elements and heavy metals accumulation in vegetable species. Food \& Feed Research, $41(2), 115-124$

Odobasic, A., Sestan, I., \& Bratovcic, A. (2017). Extraction of heavy metals from vegetable samples. ingredients. In A. M. Grumezescu, \& A. M. Holban AM (Eds.), Ingredients extraction by physicochemical methods in food (pp. 253-273). Cambridge, UK: Academic Press.

Pajević, S., Arsenov, D., Nikolic, N., Borisev, M., Orcic, D., Zupunski, M., \& Mimica-Dukic, N. (2018). Heavy metal accumulation in vegetable species and health risk assessment in Serbia. Environmental Monitoring and Assessment, 190(8), Article 459. https://doi.org/10.1007/s10661-018-6743-y

Pan, X. D., Wu, P. G., \& Jiang, X. G. (2016). Levels and potential health risk of heavy metals in marketed vegetables in Zhejiang, China. Scientific Reports, 6, Article 20317. https://doi.org/10.1038/srep20317

Peng, L., Jia, J., Daihui, Z., Jingli, X., Xueshu, X., \& Dongzhi, W. (2004). In vitro and in vivo antioxidant activities of a flavonoid isolated from celery (Apium graveolens L. var. dulce). Food \& Function Journal, 5, 50-56.

Perez-Gutierre, R., Muniz-Ramirez, A., Campoy, A. H. G., Flores, J. M. M., \& Flores, S. O. (2018). Polyphenols of leaves of Apium graveolens inhibit in vitro protein glyction and protect RINm5F cells against methylglyoxal-induced cytotoxicity. The Functional Foods in Health and Disease, 8(3), 193-211. https://doi.org/10.31989/ffhd.v8i3.399

Popova, M., Stoyanova, A., Valyovska-Popova, N., Bankova,V., \& Peev, D. (2014). A new coumarin and total phenolic and flavonoids content of Bulgarian celeriac. Bulgarian Chemical Coтmunications, 64(A), 88-93.

Popović, M., Kaurinović, B., Jakovljević, V., MimicaDukić, N., \& Bursać, M. (2007). Effect of parsley extract on some biochemical parameters of oxidative stress in mice treated with $\mathrm{Cl} 4$. Phytotherapy Research, 21(8), 717-723. https://doi.org/10.1002/ptr.2134

Pyne, S., \& Santra, S. C. (2017). Accumulation of arsenic, copper and iron in common medicinal plants of Murshidabad district, West Bengal, India. Journal of Experimental \& Clinical Cancer Research, 9, 54-62.

R Development Core Team R (2016). A language and environment for statistical computing. R Founda- tion for Statistical Computing, Vienna, Austria. https://www.R-project.org/

Rusin, M., Domagalska, J., Rogala, D., Razzaghi, M., \& Szymala, I. (2021). Concentration of cadmium and lead in vegetables and fruits. Scientific Reports, 11, Article 11913. https://doi.org/10.1038/s41598-021-91554-z

Savić, R., Ondrasek, G., \& Josimov-Dundjerski, J. (2015). Heavy metals in agricultural landscapes as hazards to human and ecosystem health: a case study on zinc and cadmium in drainage channel sediments. Journal of the Science of Food and Agriculture, 95, 466-470. https://doi.org/10.1002/jsfa.6515

Singleton, V. L., Orthofer, R., \& Lamuela-Raventos, R. M. (1999). Analysis of total phenols and other oxidation substrates and antioxidants by means of Folin-Ciocalteu reagent. Methods in Enzymology, 299, 152-178. https://doi.org/10.1016/S0076-6879(99)99017-1

Soler-Rivas, C., Espín, J. C., \& Wichers, H. J. (2000). An easy and fast test to compare total free radical scavenger capacity of foodstuffs. Phytochemical Analysis, 11, 330-338.

https://doi.org/10.1002/1099-

1565(200009/10)11:5<330::AIDPCA534>3.0.CO;2-G

Stankevićius, M., Akunaca, I., Jacobsone, I., \& Maruška, A. (2011). Comparative analysis of radical scavenging and antioxidant activity of phenolic compounds present in everyday use spice plants by means of spectrophotometric and chromategraphic methods. Journal of Separation Science, 34, 1261-1267. https://doi.org/10.1002/jssc.201000915

Strategija vodosnabdevanja i zaštite voda u AP Vojvodini. Univerzitet u Novom Sadu, Prirodno-matematički fakultet, Departman za hemiju. (2009). http://www.ekourbapv.vojvodina.gov.rs/wpcontent/uploads/2018/09/sajt-strategijavodosnabdevanja-i-zastite-voda-apv.pdf

Ulusu, Y., Ozturk, L., \& Elmastas, M. (2017). Antioxidant capacity and cadmium accumulation in parsley seedlings exposed to cadmium stress. Russian Journal of Plant Physiology, 64(6), 883-888. https://doi.org/10.1134/S1021443717060139

U.S. EPA. (2014). Method 6020B (SW-846): Inductively Coupled Plasma-Mass Spectrometry, Revision 2. Washington, DC.

Wuana, R. A., \& Okieimen, F. E. (2011). Heavy metals in contaminated soils: A review of sources, chemistry, risks and best available strategies for remediation, ISRN Ecology, e402647. https://doi.org/10.5402/2011/402647. 


\title{
SADRŽAJ ARSENA I FENOLNIH JEDINJENJA U PERŠUNU (PETROSELINUM CRISPUM (MILL.) FUSS) I CELERU (APIUM GRAVEOLENS L.) GAJENIH NA PODRUČJU VOJVODINE, SRBIJA
}

\author{
Slobodanka P. Pajević ${ }^{1}$, Neda M. Mimica-Dukić ${ }^{2}$, Ivana M. Nemeš ${ }^{2}$, Milan D. Župunski ${ }^{1}$, Nataša D. Simin ${ }^{2}$, \\ Malcolm A. Watson ${ }^{2}$, Danijela D. Arsenov ${ }^{1 *}$ \\ ${ }^{1}$ Univerzitet u Novom Sadu, Prirodno-matematički fakultet Univerziteta u Novom Sadu, Departman za biologiju \\ i ekologiju, Trg Dositeja Obradovića 3, 21000, Novi Sad, Srbija \\ ${ }^{2}$ Univerzitet u Novom Sadu, Prirodno-matematički fakultet Univerziteta u Novom Sadu, Departman za hemiju, \\ biohemiju i zaštitu životne sredine, Trg Dositeja Obradovića 3, 21000, Novi Sad, Srbija
}

Sažetak: Veliki broj biljaka iz familije Apiaceae, među kojima su peršun i celer, se koristi u svakodnevnoj ishrani kao povrće bogato vitaminima, mineralima, biološki aktivnim jedinjenima i antioksidativnim svojstvima. Međutim, povrtarske vrste mogu sadržati povećenane koncentracije polutanata, poput teških metala, što može uticati na smanjeni kvalitet povrća i negativno uticati na zdravlje ljudi. U cilju utvrđivanja kvaliteta peršuna i celera gajenih na teritoriji Vojvodine (Srbija) uzorci navedenih vrsta su prikupljeni sa različitih lokaliteta i određen je sadržaj arsena (As), kao i sadržaj biološki aktivnih jedinjenja i antioksidativnog kapaciteta. Rezultati su pokazali da se koncentracija arsena kretala u rasponu: koren peršuna $(0,16 \mu \mathrm{g} / \mathrm{g}$ d.m. $)<$ koren celera $(0,19 \mu \mathrm{g} / \mathrm{g} \mathrm{d.m})<$. list peršuna $(0,35 \mu \mathrm{g} / \mathrm{g}$ d.m. $)<$ list celera $(0,45 \mu \mathrm{g} / \mathrm{g}$ d.m. $)$. Sadržaj ukupnih fenola se nije signifikantno razlikovao između vrsta, ali je značajno varirao u zavisnosti od mesta gajenja i kretao su u opsegu: 5,03-9,18 mg eqGA/g u peršunu i 5,04-8,50 mg eqGA/g u celeru. Takođe, dobijeni rezultati su ukazali na blagu do umerenu antioksidativnu aktivnost obe vrste, dok su značajne razlike utvrđene između lokaliteta gajenja. Kada su u pitanju ukupni fenoli, niži sadržaj je zabeležen u korenu celeru. Među fenolnim kiselinama dominirale su ferulna, hlorogena i cimetna kiselina. Apigenin i njegovi glukozidi su dominirali među flavonoidima. Na osnovu analize glavnih komponenti (PCA analiza) može se zaključiti da je sadržaj As varirao u zavisnosti od geografskog porekla uzoraka. Takođe, značajan doprinos u razdvajanju grupa u PCA analizi pokazuje fenolni profil, kao i kumarini koji su doprineli radvajanju uzoraka na osnovu lokaliteta gajenja.

Ključne reči: arsen, povrće, antioksidativni odgovor, fenolna jedinjenja, PCA analiza

Received: 27 October2021 / Received in revised form: 30 November 2021 / Accepted: 15 December 2021

Available online: December 2021

This is an open-access article under the CC BY license (http://creativecommons.org/licenses/by/3.0). 